\title{
Seeing Migration like a State: The case of irregular Indonesian migrant workers deported from Malaysia
}

\author{
Benny Hari Juliawan
}

\begin{abstract}
The corridor linking Indonesia with Malaysia is particularly rife with transborder mobility, including large-scale labour migration. While irregularity has long been a major feature of these flows, much of the movement now falls under the migration regimes adopted by Malaysia and Indonesia. Long-established casual migration flows collide with recently codified norms and, as a result, oscillate between regularity and irregularity. This paper explores the following questions: How does the regulatory state view and handle undocumented migrants? How does it interact with established social networks that have facilitated irregular labour migration? Particular attention is given to the distinction between the categories of deportable criminals and victims deserving protection, as ascribed by state actors to certain groups of migrants. Based on interviews with twelve deported Florenese migrant workers, the paper discusses how the Indonesian-Malaysian migration regime seeks to shape mobility. It argues that shifting categorisations reflect political imperatives more than the migrants' needs that prompt them to migrate in the first place.
\end{abstract}

Keywords: deportation, Indonesia, criminal/victim, Malaysia, irregular migration

Please cite this article as: B H Juliawan, 'Seeing Migration like a State: The case of irregular Indonesian migrant workers deported from Malaysia', AntiTrafficking Review, issue 11, 2018, pp. 36-51, www.antitraffickingreview.org

This is an open-access article distributed under the terms of the Creative Commons Attribution License (CC-BY). Under the CC-BY license, the public is free to share, adapt, and make commercial use of the work. Users must always give proper attribution to the authors and the Anti-Trafficking Review. 


\section{Introduction}

Irregularity has long been a major feature in Indonesia's labour migration. The corridor linking the country with Malaysia is particularly rife with this irregular transborder mobility. Since colonial times, migrants from the island of Flores have plied the route both to East and West Malaysia in search of better livelihoods and adventure. ${ }^{1}$ Much of this movement now falls under the migration regimes adopted by Malaysia and Indonesia. Consequently, longestablished casual migration flows now collide with recently codified norms. Migrants have developed a wide array of responses to this new challenge, ranging from outright resistance to reluctant compliance with legal requirements. As a result, migration flows oscillate between regularity and irregularity.

A crucial element in these dynamics is the desire of the state, both in Malaysia and Indonesia, to bring the cross-border movement of people under its control. The underlying logic is strongly informed by economic considerations, given the income and employment gaps between the two neighbouring countries. While Indonesia suffers from chronic unemployment and low wages, Malaysia's economy depends heavily on foreign workers, who make up around 15 to 25 per cent of the total labour force. ${ }^{2}$ Labour migration between the two countries offers real opportunities to address these issues, and the prospect of mutual benefits has encouraged the two governments to facilitate the movement of workers, notwithstanding occasional tensions illustrated by the deportation of around 400,000 Indonesian migrants from Malaysia in $2002 .^{3}$

1 I B Mantra, 'Indonesian Labour Mobility to Malaysia (A case study: East Flores, West Lombok, and the Island of Bawean)' in Sukamdi, A Haris and P Brownlee (eds.), Labour Migration in Indonesia: Policies and practice, Population Studies Centre UGM, Yogyakarta, 2000, pp. 143-184.

2 Given an unknown number of undocumented migrant workers, figures reported vary considerably. An old estimate from 2008 quotes a figure of 25 per cent. See: V Kanapathy, Controlling Irregular Migration: The Malaysian experience, ILO, Bangkok, 2008. More recent survey data for 2016 mention 15.6 per cent (Labour Force Survey), 17 per cent (National Employment Returns), and 24.4 per cent (independent estimate). See: L Hwok-Aun and K Y Leng, 'Counting Migrant Workers in Malaysia: A needlessly persisting conundrum', ISEAS Perspective, no. 25, 2018, pp. 7-8.

3 M Ford, 'After Nunukan: The regulation of Indonesian migration to Malaysia' in A Kaur and I Metcalfe (eds.) Mobility, Labour Migration and Border Controls in Asia, Palgrave Macmillan, New York, 2006, pp. 228-247. 
Modern statecraft determined to bring about social order is well captured in James Scott's Seeing Like A State (1998). ${ }^{4}$ Scott highlights how nation-states are premised on a vision of large-scale social engineering and seek to develop the requisite capacity and tools. In this context, society is often perceived as a chaotic entity separate from the state: '[It] became an object that the state might manage and transform with a view toward perfecting it. ${ }^{5}$ The improvement of all members of society is a central purpose of the modern state, in addition to the classic goals of taxation, conscription and prevention of rebellion. At the same time, similar to earlier efforts at theorising the modern state, ${ }^{6}$ Scott's work points out the flip side of state ambitions to order social life. Social engineering is necessarily schematic and limited; it objectifies society and conceptualises its features according to its own needs, such as the requirements of urban planning, industrial production, settlement or land ownership. This simplified picture or map feeds into plans for control and interventions, which are often at odds with a functioning social order. Little wonder, therefore, that such efforts often fall short of their objectives and, in some cases, yield disastrous results as the tragedies cited in Scott's book illustrate.

Labour migration policies are a case in point: they frame the movement of people in terms of national interests including economic growth and border control. ${ }^{7}$ However, such policies often ignore the social and political dimensions of labour migration, especially in a context where social networks significantly shape migration opportunities. This paper unpacks these complex dimensions as 'systematically interlinked technologies, institutions, and actors that facilitate and condition mobility'. ${ }^{8}$ Different factors are at play, colliding, collaborating and shaping mobility. An important element in the process are the shifts in the designation of migrants, who are in some context seen as criminals deserving punishment and in others as victims meriting help and

J C Scott, Seeing Like A State, Yale University Press, New Haven, 1998.

Ibid., p. 92.

Z Bauman, Modernity and the Holocaust, Polity Press, Cambridge, 1991.

M Ford, L Lyons and W van Schendel, 'Labour Migration and Human Trafficking: An introduction' in M Ford, L Lyons and W van Schendel (eds.), Labour Migration and Human Trafficking in Southeast Asia: Critical perspectives, Routledge, Abingdon, 2012, pp. 1-22.

8 J Lindquist and B Xiang, 'The Infrastructural Turn in Asian Migration' in G LiuFarrer and B S A Yeoh (eds.) Routledge Handbook of Asian Migrations, Routledge, London, 2018, p. 154. 
protection - a contradiction that has attracted interest in research within critical trafficking and deportation studies. ${ }^{?}$

Following the deportation from Malaysia of twelve migrant workers from Raburia village in Ende district, Flores, Indonesia, this paper discusses how the experience of deportation is shaped by shifting legal regimes in Malaysia and Indonesia, as well as by the migrants' multiple vulnerabilities. Arrested and punished as criminals in Malaysia, the twelve workers were deported back to Indonesia, where state authorities treated them as victims.

\section{Modern Statecraft in Controlling Migration}

For Malaysia and Indonesia, necessities dictate the management of migrant workers. Although labour importation had started in colonial times, Malaysia's reliance on migrant workers became more acute after the start of the exportindustrialisation drive in the early 1980s, which triggered massive urbanisation at the expense of the agricultural sector. In-migration at that stage was perceived only as a temporary solution to 'sustain labour market demand and to maintain Malaysia as a favourable site to foreign investors'. ${ }^{10}$

Over the years, it became clear that the demand for migrant workers was anything but temporary. Employment prospects in Malaysia motivated Indonesian workers to cross the border even without proper documents, their movement facilitated by a relaxed attitude to irregularity among many state officials on both sides of the border. To illustrate, the number of irregular migrant workers in Malaysia increased from an estimated 1.9 million in 2010 to 2.5 million in 2014. ${ }^{11}$ In addition, a tacit recognition of Malaysia's heavy reliance on foreign labour often revealed itself in policy reversals following

9 S Plambech, "Between "Victims" and "Criminals": Rescue, deportation and everyday violence among Nigerian migrants', Social Politics, vol. 21, no. 3, 2014, pp. 382-402; E Paasche, ML Skilbrei and S Plambech, 'Vulnerable Here or There? Examining the vulnerability of victims of human trafficking before and after return', Anti-Trafficking Review, issue 10, 2018, pp. 34-51.

10 E S Devadason and C W Meng, 'Policies and Laws Regulating Migrant Workers in Malaysia: A critical appraisal', Journal of Contemporary Asia, vol. 44, no. 1, 2014, p. 22.

11 C C Low and K S Mokhtar, 'Deportation Turn in Malaysia: Expansion, discourse and practice', Journal of Population and Social Studies, vol. 25, no. 2, 2017, p. 148. 
crackdowns on irregular migrants. ${ }^{12}$ Such reversals are actually indicators of different views among state institutions regarding migrant workers. The Malaysian Ministry of Human Resources and other related ministries recognise the importance of foreign labour to the economy. On the other hand, the Ministry of Home Affairs sees migrant workers as a security issue that has to be responded to with increased surveillance and reduction in numbers.

Irrespective of occasional reversals, Malaysian policies have shown an overall trend towards increased border control. Low and Mokhtar describe the country's current migration governance as a 'deportation regime' and divide its development into four periods: 1) pre-1992 (securitisation of operations); 2) 1992-2002 (militarisation of operations); 3) 2002-2010 (zero-tolerance policy); and 4) post-2010 (deportation turn). ${ }^{13}$ Each period is characterised by increasingly punitive policy measures. For example, in 1992 the government launched the two-pronged Operation Expunge (Ops Nyah) to counter irregular migration. While the police assumed responsibility for preventing new arrivals (Ops Nyah I), the military was deployed to arrest irregular migrants already in the country (Ops Nyah II). Caning was introduced in 1997 for 'double backers', or deportees who returned to Malaysia as irregular migrants, and expanded to first-time offenders in 2002. A biometric system was launched in 2005 to prevent re-entry. In the 2010 s, the government fundamentally reformed the 'deportation regime' by increasing the capacity of detention centres, by expediting trials and deportations and by collaborating with the governments of sending countries and with international agencies such as the UN High Commissioner for Refugees, the International Committee of the Red Cross and the International Organization for Migration. As of 2015, the Malaysian government ran fourteen permanent and three temporary detention facilities with a total capacity of 18,350 inmates. ${ }^{14}$

Across the border, the Indonesian government responded to the end of the oil bonanza in the early 1980s by initiating labour out-migration policies 'to mitigate the unemployment problem, to increase skills and working experience abroad and to improve the foreign exchange position'. ${ }^{15}$ Indonesia joined a growing group of developing countries with labour surpluses, which integrated

12 Kanapathy.

13 Low and Mokhtar, p. 148.

14 Ibid., p. 155.

15 G Cremer, 'Deployment of Indonesian Migrants in the Middle East: Present situation and prospects', Bulletin of Indonesian Economic Studies, vol. 24, no. 3, 1988, p. 78. 
overseas employment into their national development strategies. ${ }^{16}$ Formal protections only came much later with Law no. 39 of 2004 on the protection and placement of Indonesian overseas workers, and its subsequent replacement, Law no. 18 of 2017. Over time, migrant workers' contributions to the national economy increased steadily. By 2015, remittances had reached USD 10.5 billion and amounted to just over one per cent of the country's GDP. ${ }^{17}$ Government parlance accordingly glorifies migrant workers as 'pablawan devisa' or 'heroes of foreign exchange'.

Such narratives of success are often accompanied by reports about the hardship and abuses suffered by Indonesian workers abroad. Accounts from the early period of labour migration painted a gloomy picture: workers suffered from 'very long working hours, sometimes from dawn to after midnight, payments below the amount stated in the contract, delays in payment, berating and beating, or sexual abuse and rape'. ${ }^{18}$ A report on Indonesian plantation workers in Sabah, Malaysia, described their conditions as 'bonded labour... modern kind of slavery'. ${ }^{19}$

Public outcries and pressures from civil society groups bore fruit with the ratification of the UN Convention on the Protection of the Rights of All Migrant Workers and Members of Their Families in 2012. However, it took five years and various legal drafts before a new law implementing the Convention was passed (Law no. 18 of 2017). This protracted legislative process suggests that labour migration is still very much a contested space between business profitability and efficiency, on the one hand, and measures to provide protection to workers, on the other.

These shifts in government policies and narratives help condition the mobility of migrant workers. The regulatory dimension of the migration regime prescribes the appropriate treatment of migrants in various situations and informs the reactions of people around them, but, as I argue in this paper, it does not always produce the intended perceptions and experiences of migration on the part of the migrants themselves.

16 C B Chin, Walls of Silence and Late Twentieth Century Representations of the Foreign Female Domestic Worker: The case of Filipina and Indonesian female servants in Malaysia', International Migration Review, vol. 31, no. 2, 1997, pp. 353-385.

17 World Bank, Migration and Remittances Factbook. 2016, World Bank, Geneva, 2016, p. 21.

18 Cremer, pp. 81-82.

$19 \mathrm{~T} \mathrm{M} \mathrm{Li}$, 'To Make Live or Let Die? Rural dispossession and the protection of surplus populations', Antipode, vol. 41, 2009, p. 77. 


\section{Methods}

This paper is based on a research project to understand the phenomenon of repatriation, funded by the migration network of the Jesuit Conference of Asia Pacific (JCAP). Primary data were collected by interviewing twelve Florenese male construction workers, ranging from 16 to 56 years of age, who were deported from Malaysia having been caught without proper documents in September 2015. Employment on plantations and in the construction sector in Malaysia is taken up mostly by migrant workers, comprising around 70 per cent of the sectors' total workforce in 2014, according to the Malaysian Employers Federation. ${ }^{20}$ Men dominate the physically demanding work in these sectors, and Florenese men, in particular, are perceived as capable of such hard outdoor labour, thought to resemble work in their home villages.

The interviews took place in February 2016, while the workers were in a temporary shelter in Jakarta, and on two separate occasions in June and November 2016, when they were back home. In the shelter, group interviews were conducted because it was difficult to arrange separate conversations in a crowded space. Moreover, an exclusive interview would have made the respondent stand out and feel uncomfortable. In the village, two local contact persons helped establish rapport with the village chief, who himself had gone twice to Malaysia as a plantation worker. The chief knew the deportees and their stories and endorsed my fieldwork, which, given his authority, facilitated my interviews. In the safety of their home village, the respondents were more outspoken, although private interviews still made them uncomfortable because they were not familiar with the concept of interviewing. In the end, four of the twelve agreed to be interviewed individually while the others were interviewed as a group. All twelve agreed to the publication of their names. A longer stay with the respondents would probably have yielded richer insights, but the JCAP research grant was very limited and could not support more extensive fieldwork.

To corroborate the data, interviews were also conducted with ten other former male migrant workers in Malaysia from a neighbouring village. These men went to Malaysia in different periods but their experiences confirmed the stories of the migrants from Raburia: undocumented mobility, multiple entries to Malaysia, working in plantations and construction sites, arrest and deportation. The fieldwork also included interviews with five local activists and three officials from local authorities in Ende district, who were responsible for labour

20 Hwok-Aun and Leng, p. 7. 
migration affairs. Further, government records in Jakarta and in Ende supplement the interview data.

\section{Criminalising a Functioning Labour Migration}

The ordeal of the twelve returnees from Raburia in Ende began when the van they were travelling in was stopped by the police on a road in Kampung Gajah area in Perak, Malaysia, in the middle of the night sometime in September 2015. They were part of the 256 irregular migrants that were arrested daily that year, of whom one third were Indonesians. ${ }^{21} \mathrm{Up}$ to that point, the men had been working as a group for the same employer on a construction site. That evening they were being transported to a new site where they were to start their work the following morning. When the men could not produce documents, the police immediately detained them along with the Malaysian driver, who was released shortly afterwards.

Despite hailing from the same village and being arrested as a group, the men actually did not come to Malaysia at the same time. Xaverius (42 years old) and Bartolomeus (30 years old) were veteran migrants who had been in and out of Malaysia four times, each lasting from one to two years; Kasimirus (40 years old) had been to Malaysia three times; and the teenager Heribertus (17 years old) had previously been to Malaysia when he was only 12 years old. For the others, this was their first migration to Malaysia, and they had been in the country between one and six months prior to the arrest. All of them were never in possession of proper documents while in Malaysia.

The men had known each other, being neighbours and some even relatives in the same village. In fact, it is quite common for Indonesian migrants to bring friends and relatives to Malaysia to work in the same place, a practice that is encouraged and facilitated by employers. Xaverius brought his neighbour with him when going back to Malaysia for the second time, and Heribertus followed his uncle to work in a plantation back in 2011. The village network or indeed the network of people from the same district shapes the migration process in a way that has become convenient to both migrants and employers: the migrants need not spend time looking for jobs while the employers can access a pool of labourers from a distance. Furthermore, this informal channel reduces costs both for the employers, who circumvent the requirements for work permits,

${ }^{21}$ Low and Mokhtar, p. 157. 
and for the prospective workers, who bypass lengthy and bribery-ridden placement bureaucracies. ${ }^{22}$

The same network supports the return of the migrants. Extensive knowledge of the migration route and leverage with relevant officials on both sides of the border facilitate a smooth journey back home. Indeed, the border between the two countries is made porous partly by corrupt immigration officers, whose involvement is often ignored in law enforcement efforts targeting only migrants and their immediate handlers. ${ }^{23}$

The current circular labour migration inserts itself into a long-established pattern linking Flores and Malaysia. Seafaring communities had moved within the region long before the colonial era. The British added a new dimension to these migratory flows when they imported foreign workers from South China, the Philippines, India and Indonesia for the growing economy of colonial Malaya. Some of these workers settled and later became citizens of independent Malaysia. ${ }^{24}$ Once established, networks of migrants often acted as sponsors and helped to facilitate the arrival of more migrant workers when there was demand in subsequent periods. The influx of migrants from Flores, in particular, became greater after the introduction of large-scale agricultural estates and the rise of the timber industry in the 1950s. ${ }^{25}$ Combining traditional kinship networks and trans-border mobility, the Florenese over time established a vast network of labour migration with outposts in many places along the routes that connect Flores and Malaysia. In fact, given the extent of the network that now straddles the border between Indonesia and Malaysia in places like East and West Kalimantan and the Riau Islands, one scholar suggests that the Florenese constitute an embryonic transnational community. ${ }^{26}$

The arrest of the twelve migrant workers by the Malaysian authorities interrupted this otherwise functioning system of labour allocation. Driven by the vision of order, the authorities committed what Scott calls 'state

22 G Hugo, 'Best Practice in Temporary Labour Migration for Development: A perspective from Asia and the Pacific', International Migration, vol. 47, no. 5, 2009, p. 30.

23 A M Nah, 'Globalisation, Sovereignty and Immigration Control: The hierarchy of rights for migrant workers in Malaysia', Asian Journal of Social Science, vol. 40, no. 4, 2012, pp. 486-508.

24 Mantra, p. 144.

25 R Tirtosudarmo, On the Politics of Migration: Indonesia and beyond, LIPI Press, Jakarta, 2015, p. 217.

26 Ibid., p. xxxv. 
simplification' in treating the detained men mainly as individuals to be punished for a criminal activity. Just the same, some scholars suggest that the Malaysian policies on in-migration are deliberately designed to leave a grey area that can be exploited to fulfil the continuous demand for migrant workers. ${ }^{27}$ In any event, arrests by the authorities do not always spell the end of employment in Malaysia. The presence of millions of undocumented migrant workers would not be possible without some degree of complicity on the part of the authorities. Arrests sometimes simply serve as a way to solicit bribes. Xaverius and his friends noted that they actually tried to offer some money to the policemen that night. However, the checkpoint was being supervised by a high-ranking officer and so the policemen on duty did not accept the bribes offered.

The police took the group to a detention facility in Sri Iskandar. After three weeks, the men were transferred to a prison in Taiping, where they had to go on trial. They were found guilty of working irregularly and sentenced to six months' imprisonment, for which the authorities moved them to yet another prison in Tapah. Life in detention was hard, and the money the men had on them at the time of their arrest was taken away without explanation. When the men had served two-thirds of their term in Tapah prison, the Malaysian authorities deported the group to Indonesia.

\section{The Construction of Victimhood in Indonesia}

Once the men set foot on Indonesian soil, the social protection regime kicked in. Unlike in Malaysia, the migrants were not treated as criminals, although they had clearly broken the Indonesian laws on migrant worker placement and immigration. Instead, the Indonesian authorities treated the men as victims deserving assistance and protection. This response came automaticallyofficials made no attempt to check whether the men had suffered any injustice or exploitation. In particular, nothing was done to ascertain whether they had become victims of human trafficking. The authorities' approach was probably informed by a popular perception that the government is incapable of protecting its own citizens. ${ }^{28}$

\section{Devadason and Meng.}

28 Public outcries criticising perceived government inaction usually follow news of Indonesian migrant workers executed abroad for alleged crimes or when cases of abuse surface, such as the one about Erwiana who was physically tortured by her employer in Hong Kong in 2013. 
For a number of reasons, however, treatment as victims does not necessarily qualify returnees to seek redress in the Indonesian justice system. First, provisions for redress mainly concern administrative dispute resolutions and insurance schemes, which only apply to documented migrants. Second, the Indonesian judicial system (e.g. for cases of human trafficking) is notoriously treacherous. Individuals seeking justice face systemic barriers such as cost, time, the need for expertise as well as perceived bias and corruption. In addition, migrant workers often suffer from multiple vulnerabilities such as poverty, low levels of education and little formal work experience, rendering the barriers to justice even greater.

The provision of state protection comes together under the policy framework for 'Pekerja Migran Bermasalah' (PMB), or 'Migrant Workers with Problems'. ${ }^{29}$ The Decree of the Minister of Social Welfare no. 22/2013 defines these as: 'Indonesian overseas migrant workers who have no work permits, legal documents, and/or who work in violation of their work permits, [and have] encountered problems in terms of violence, exploitation, deportation, neglect, social disharmony, [or] inability for self-adjustment.' The decree also stipulates that the Ministry of Social Welfare is responsible for repatriating the returnees from the point of arrival in Indonesia to their home province where regional governments take over the process and provide them with transportation to their home districts and eventually on to their villages.

This shift in the categorisation of the men as they returned from Malaysia to Indonesia reflects the ongoing discussion about the linkage between 'deportable criminals and virtuous victims deserving of protection' ${ }^{30}$ Indeed, as has been highlighted in research on other populations, both criminalisation in Malaysia and victimhood in Indonesia do not reflect the main experiences of the deported individuals, as illustrated later.

From Port Klang in Malaysia, the group arrived in Tanjung Balai, North Sumatra, and was immediately taken to a rehabilitation centre for victims of domestic violence and exploitation, run by the Ministry of Social Welfare and known as Rumah Perlindungan dan Trauma Centre (RPTC), or House of Protection and Trauma Centre. The shelter authorities banned the men from

29 For extensive descriptions of Indonesia's legal frameworks of assistance for trafficking victims, migrant workers and vulnerable persons, see: R Surtees et al., Going Home. Challenges in the reintegration of trafficking victims in Indonesia, Nexus Institute, Washington DC, 2016.

30 See, for example, Plambech's work on Nigerian sex workers in Europe; Plambech, p. 384 . 
going out — a measure usually taken to prevent a return to Malaysia. Although the migrants from Flores found themselves confined to the facility, the regime of the shelter did not include any activities to help them pass their time. After ten long days, the men were taken by boat to Tanjung Priok port in Jakarta. Upon arrival, the authorities gave each of them IDR 250,000 (USD 17.5) as pocket money, and they were immediately taken to the RPTC in East Jakarta run by the Ministry of Social Welfare, a large facility handling an increasing number of PMBs. ${ }^{31}$

The mandate of RPTCs as outlined in the Decree of the Ministry of Social Welfare no. 102/2007 is quite comprehensive. The centres are to provide food, temporary accommodation, and clothing to their clients and to offer healthcare, including psycho-social rehabilitation and trauma healing. The shelters are also supposed to prepare the returnees for reintegration with their families and communities, in collaboration with regional governments. Moreover, the RPTCs play the role of crisis centres. Finally, they are tasked with gathering information from returnees and running public information campaigns on migration.

However, an internal review commissioned by the Ministry in 2015 criticised the centres for failing to meet their responsibilities. ${ }^{32}$ RPTCs operate on a very small budget and each institution only employs one or two civil servants, who work as the coordinator and secretary, assisted by volunteers. The review mentions, for example, how the RPTC in Bambu Apus Jakarta struggles with the financial burden of having to feed and repatriate an increasing number of deported migrants. High medication bills for serious cases of illness or injury stretch the meagre budget even further. The recently established national health insurance scheme is of little help as it requires identity documents that undocumented migrants are lacking.

The twelve men from Raburia luckily did not have serious physical or mental problems. It was mostly boredom that troubled them while in the shelter. They spent about a week in the facility until, on 13 February 2016, they were taken back to Tanjung Priok port from where they travelled by boat to Maumere in Flores. No staff from the RPTC or from any government agency

31 In 2013, this facility handled 763 returnee migrants; in 2014, the figure was 935; and by June 2015, the figure was already 769; Kementrian Sosial, Perlindungan Sosial Pekerja Migran Bermasalab melalui Rumah Perlindungan Trauma Center, Kementrian Sosial, Jakarta, 2015, p. 35.

32 Husmiati et al., Perlindungan Sosial Pekerja Migran Bermasalah melalui Rumah Perlindungan Trauma Center, P3KS Press, Jakarta, 2015. 
accompanied them on the trip. They were given tickets, a little more money and an official cover letter to be handed over to the Dinas Sosial, the Office of Social Welfare, in Maumere. The boat took four days to reach the men's destination. Once disembarked, the group was supposed to go to the Dinas, report their arrival and receive further assistance, but by the time the vessel reached the port it was late in the evening, and the office of the Dinas was closed. Although aware of the instructions from Jakarta, the men 'could not be bothered to wait until dawn to access the Dinas' as Xaverius, the de facto leader of the group, would later report. '[They] simply wanted to get home as soon as possible.' Their village could not be directly reached by cars. From Maumere, it would take them about four hours on the road to travel to a point from which relatives could take them home on motorbikes. The men decided to use what remained of the pocket money they had received for the trip and mobilised their kinship network to arrange their journey.

The repatriation procedure stipulates that, once returnees arrive in the provincial port, the local government agencies will take over from the ministry and accompany them to their home villages. In reality, no one in the Dinas in Maumere or Ende was aware of the Raburia returnees. 'I have double-checked. We do not know anything about the deported migrants from Raburia,' confided Romanus Tato, the head of the department of social security and assistance of the Dinas Sosial in Ende. Similarly, Yoseva Dewi, the head of the responsible department in the Dinas Tenaga Kerja, or Labour Agency, in Ende knew nothing of them.

This lack of coordination is often blamed on the decentralisation policy that started in 2001 as part of the political reform following the demise of the New Order regime. Decentralisation is supposed to encourage greater public participation in development by transferring some of the powers from Jakarta to the regions. It is meant as a means of improving public services, reducing inefficiency and corruption, and deepening democracy. ${ }^{33}$ Under this policy, local governments are authorised to reorganise departmental offices and reallocate the resources according to their priorities. Whatever its benefits in other areas, however, the decentralisation policy often complicates coordination between the various levels of government.

33 J Manor, The Political Economy of Democratic Decentralization, The World Bank, Washington DC, 1999; A Dasgupta and V A Beard, 'Community Driven Development, Collective Action and Elite Capture in Indonesia', Development \& Change, vol. 38, no. 2, 2007, pp. 229-249. 
The Ministry of Social Welfare and the related Dinas in the regions are part of a special task force, or satgas, that is responsible to facilitate the safe return of deported migrants in each region. Other members are delegated by the coordinating Ministry of People's Welfare, the Ministry of Home Affairs, the Ministry of Law and Human Rights, the Ministry of Labour and Transmigration, the Ministry of Health, the Ministry of Women's Empowerment and Child Protection and the National Agency for the Protection and Placement of Indonesian Migrant Workers (BNP2TKI). ${ }^{34}$ In reality, though, only officials from the local Dinas of Social Welfare, the local Dinas of Labour and Transmigration, and the local representatives of BNP2TKI are present in the field, albeit not always in a coordinated manner. On various occasions, officials from the agencies complained about the lack of collaboration and a culture of blaming other institutions in areas of shared responsibility. ${ }^{35}$

\section{Life after Deportation}

Back in the village, the men quickly resumed their routines in the field, but problems remained: all had taken out loans to finance their trip to Malaysia and were struggling to repay their debts - an issue also documented by another study on migrant workers in the area. ${ }^{36}$ According to the villagers interviewed, locals typically borrow money from loan sharks who charge a fixed annual interest rate of 100 per cent even if the debtor can repay the loan in a period shorter than a year.

Such was the case of Heribertus. For his first trip to Malaysia, his mother borrowed 3 million rupiah (USD 226). After four months, he had earned enough to repay the debt of 6 million rupiah, including interest. Similarly, Bartolomeus had borrowed 5.5 million rupiah so that his total debt, including interest, amounted to 11 million (USD 828). Before he got caught, he had

34 Under the Presidential Decree no. 106 of 2004, this task force is called the Coordination Team for the Repatriation of Indonesian Migrant Workers with Problems and Their Families or TK-PTKIB in its Indonesian acronym. This legislation has been replaced by the more generic Presidential Regulation no. 45 of 2013, which does not significantly change the substance of the old law.

35 Husmiati et al., p. 60.

36 G Hugo, 'International Labour Migration and Village Dynamics: A study of Flores, East Nusa Tenggara' in T R Leinbach (ed.), The Indonesian Rural Economy: Mobility, work and enterprise, Institute of Southeast Asian Studies, Singapore, 2004, pp. 120122. 
paid 6 million rupiah from his savings of 11 months and now still had to find another 5 million. A third member of the group, Yohanes, had taken out a loan of 2 million rupiah (USD 145) and had to repay 4 million. Having worked for just a month before deportation, though, he had no money left to settle his debt.

'It is hard here. We really struggle to make ends meet. Food is not a problem, but other expenses are difficult,' said Bartolomeus, referring in particular to his child's school fees. He added, 'I have a plan to go back to Malaysia.' Xaverius was not yet decided, but would not exclude the possibility of returning to Malaysia. 'For me it would not be so soon. I do not know for sure.' These anecdotal accounts help to shed light on the reason why people from this region have continued to embark on the risky migration to Malaysia. Indebtedness, lack of education and job opportunities continue to haunt them while irregular migration, facilitated in part by established social networks, offers a real opportunity. ${ }^{37}$ Treatment as victims by Indonesian authorities does nothing to improve the living conditions of deported returnees, nor does the criminalisation of irregular migrants in Malaysia provide an effective deterrent. In other words, while the criminal/victim categorisation helps to shape mobility, it does not significantly change the structure of migration opportunities.

Further, the twelve men at the focus of this study did not face blame and rejection by their families or community for their failed adventure. At the time of the interviews, 20 out of 179 families in the village had at least one of their members, mostly men, working in Malaysia. As their remittances are essential for the families, their absence is seen as normal and potential failure of a migration as an accepted risk. This assessment is consistent with Surtees's study on the reintegration of trafficked men from Java island, and in contrast with the negative reactions returning migrant women often have to face from their communities. ${ }^{38}$

37 E Spaan and T van Naersen, 'Migration Decision Making and Migration Industry in the Indonesia-Malaysia Corridor', Journal of Ethnic and Migration Studies, vol. 44, no. 4, 2018, pp. 680-695. See also: N van Hear, O Bakewell, and K Long, 'Drivers of Migration', Migrating out of Poverty Research Programme Consortium Working Paper 1, University of Sussex, Brighton, 2012, p. 15.

38 R Surtees, 'At Home: Family reintegration of trafficked Indonesian men', AntiTrafficking Review, issue 10, 2018, pp. 70-87. See also: E Prusinski, 'Wasted Talent', Inside Indonesia, 12 April 2014, retrieved 23 July 2018, http:// www.insideindonesia.org/wasted-talent. 


\section{Conclusion}

The labour migration route that connects Indonesia and Malaysia brings together two distinct logics of operation-one of the state and another of social networks - each having distinct actors, forces and strategies. The regulatory infrastructure of the state has tried to rein in the social and commercial infrastructures of the Florenese transnational community both at the sending and receiving ends, but it gives little consideration to the complexities that inform the reproduction of labour migration and the vulnerabilities experienced by rural populations from Indonesia's outer provinces. The study of deportation offers a glimpse into those complexities.

The Indonesian and Malaysian governments do not fully recognise the ways in which the social networks of Florenese migrants shape opportunities, sanction movements and give meaning to labour migration so that village families can reap its economic benefits. The increasingly punitive migration regime devised as a tool of statecraft by Malaysia designated the Raburia men as criminals, ignoring their need for earning a living and supporting their families. Indonesian authorities, by contrast, under pressure for being unable to create employment and provide protections, responded by treating the returnee migrants as victims. In other words, both governments insist on working within the legal frameworks that primarily serve their national interests, but ignore the living conditions and needs of the migrants and their families.

The deported migrants interviewed for this study fully understood the risks and consequences of migrating without documents, but did not consider themselves victims or criminals. The shifting identification of criminal/victim reflects political imperatives more than the experiences of the migrants, who do not take centre stage and for whom the policies offer little innovation. Thus, perceiving migration like a state will not change significantly the established mobility pattern of undocumented migrants.

Benny Hari Juliawan is a lecturer in the Graduate School of Religious and Cultural Studies at Sanata Dharma University in Yogyakarta, Indonesia. His main research interests cover trade union movements, labour migration and politics of marginalised groups. Email: benny.juliawan@usd.ac.id. 